
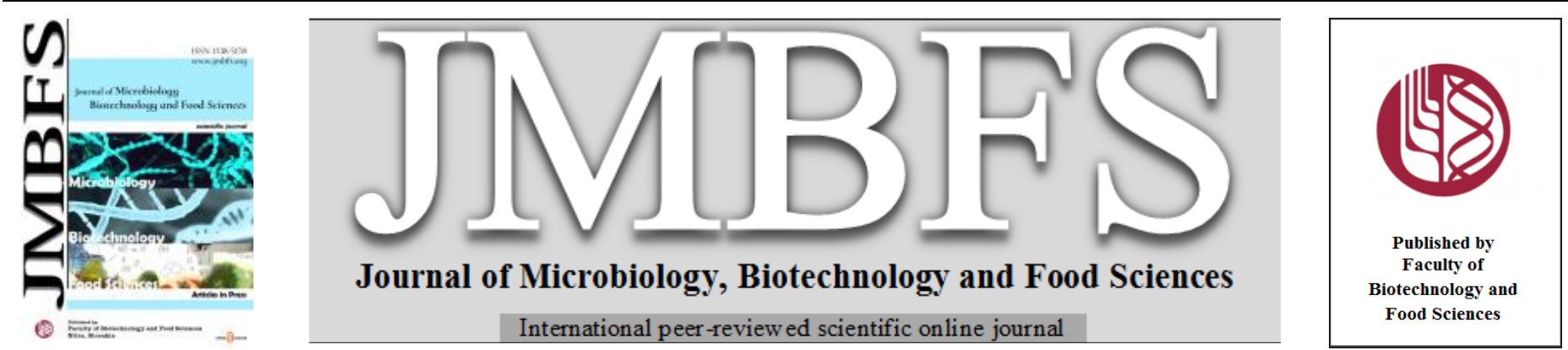

\title{
CYANOGENIC GLYCOSIDES - THEIR ROLE AND POTENTIAL IN PLANT FOOD RESOURCES
}

\author{
L'ubomír Harenčár ${ }^{l}$, Katarína Ražná*l, Janka Nôžkovál
}

Address(es): prof. Ing. Katarína Ražná, PhD.,

${ }^{1}$ Slovak University of Agriculture in Nitra, Faculty of Agrobiology and Food Resources, Institute of Plant and Environmental Sciences, Department of Genetics and Plant Breeding,Trieda Andreja Hlinku 2. 94976 Nitra, Slovak Republic, +421 376414240.

*Corresponding author: katarina.razna@uniag.sk

https://doi.org/10.15414/jmbfs.4771

ARTICLE INFO

Received 14. 5. 2021

Revised 2. 7. 2021

Accepted 2. 9. 2021

Published 1. 12. 2021

Review OPEN $\partial_{\text {ACCESS }}$

\begin{abstract}
Plants have metabolites and mechanisms that provide them with the basic building blocks for germination, growth, and reproduction processes, while providing them with protection and supporting their adaptation to environmental stresses. Due to their multifunctional significance, cyanogenic glycosides (CNG) indicate the importance of their role in the plant organism. Their diversity and biochemical origin are worth noting. Paradoxically, several nutritionally important food resources of plant origin are characterized by the presence of cyanogenic glycosides in various tissues. Processing approaches of plant food resources ensure a reduction in the content of these ingredients to an acceptable safe level. Different bacteria-based biotechnological processes are applied to minimize the content of CNG in food products. For the usability and identification of the added value of plant food resources, it is important to know the functions and importance of antinutritional components of metabolism with a consequent impact on nutrition and health. In the review we provided a comprehensive view of the importance and potential of CNG in plants with a focus on food resources, where the model object was presented by linseed.
\end{abstract}

Keywords: cyanogenic glycosides, plant food resources, linseed, Linum usitatissimum L.

\section{INTRODUCTION}

Natural phytotoxins called cyanogenic glycosides are produced by over 3000 plant species within 130 different families many of which are consumed by humans (Nielsen et al., 2016). These water-soluble secondary metabolites have a major role in the defense mechanism, regulation of the cell signaling and growth (Mosayyebi et $\boldsymbol{a l}$., 2020). In addition, the endogenous turnover of cyanogenic glycosides without the release of a hydrogen cyanide $(\mathrm{HCN})$ may offer plants an important source of reduced nitrogen and glucose at specific developmental stages (Pičmanová et al., 2015). In the edible plants were found at least 25 known cyanogenic glycosides (Bolarinwa et al., 2016). The first studies of their biosynthesis were initiated in 1967 with linen flax seedlings (Sørensen, Neilson, and Møller, 2018). The biosynthetic pathway is catalyzed by multifunctional cytochrome P450 enzymes (CYP79 and CYP71) in combination with the P450 redox partner NADPH oxidoreductase and UDP-glucosyltransferase. These enzymes are organized into a dynamic enzyme complex termed a metabolon to ensure a rapid metabolism (Gleadow and Møller, 2014). Cyanogenic glycosides are considered as anti-nutrients what means that a breeding process is set up for optimizing the composition of their beneficial nutrients and minimizing cyanogenic glycosides in the main product (Hartanti and Cahyani, 2020). Therefore, these two sides of cyanogenic glycosides lead the breeding activities to find balance between defensive responses and food safety (Sun et al., 2017).

\section{CHARACTERISTICS OF CYANOGENIC GLYCOSIDES}

Cyanogenic glycosides are a large group of the herbal secondary metabolites composed of non-sugar aglycone of $\alpha$-hydroxynitrile-type and sugar moiety (glycone) linked via a glycosidic bond (Mosayyebi et al., 2020). Cyanogenic glycosides are located in the vacuoles separated from their hydrolytic enzymes $(\beta$ glucosidases) which are in a cytosol (Duodu and Apea-Bah, 2017). In case of a cell disruption, glycosides are rapidly broken up to sugar and a cyanohydrin which is immediately degenerated to the hydrogen cyanide $(\mathrm{HCN})$ and a remaining aldehyde or a ketone (Nyirenda, 2020). The general structure of cyanogenic glycosides is presented in the figure 1 where the aglycone part is labeled as R1 and four possible positions of substituents attached to the glucose moiety as R2 - R5 (Yulvianti and Zidorn, 2021).
The cytochrome P450 (CYP) monooxygenases are probably the most catalytic biocatalysts widely founded in different life forms including multicellular eukaryotes (animals and plants), unicellular eukaryotes (fungi and protists), and prokaryotes (bacteria and archaea). They constitute a huge and intricate gene superfamily of heme-thiolate proteins that play an important role in the metabolism of various substrates (Jiu $\boldsymbol{e t}$ al., 2020). Eukaryotic P450s are type-II membraneanchored enzymes that serve as molecular platforms for anchoring metabolons to the endoplasmic reticulum. This dynamic multitasking organelle is connected to several compartments of the cell and is involved in many processes such as protein synthesis, signaling, and primary and secondary metabolism (Griffing et al., 2017). Its membrane is highly crowded with proteins which can be inadvertently competing and in hazardous crosstalk for common substrates with each other within the overlapping P450-mediated metabolic pathways (Guigas and Weiss, 2016). To avoid complications the enzymes are formed into the metabolon what is a highly specialized and dynamic complex of sequential biosynthetic enzymes responding to environmental conditions (Bassard, Moller and Laursen, 2017). In the figure 2 is a model of the metabolon responsible for linamarin synthesis in flax which includes the two membrane-anchored cytochrome P450 enzymes (CYP79D1 and CYP71E7), the membrane-anchored cytochrome P450 reductase and the soluble UDP-glucosyl transferase UGT85K (https://www.genome.jp/kegg, Kyoto Encyclopedia of Genes and Genomes) The first enzyme is a member of the CYP79 family and catalyzes the conversion of an amino acid to the corresponding aldoxime. CYP71 family member subsequently converts the aldoxime to a cyanohydrin which is afterwards stabilized by glucosylation to form the final cyanogenic glucosides in a reaction catalyzed by a UGT from the UGT85 family (Hansen et al., 2018). Nowadays, the cytochrome P450 aggregates more than 18687 protein-coding genes which are helpfully organized into families and subfamilies in view of the percentage of an amino acid similarity (Alzahrani and Rajendran, 2020). 


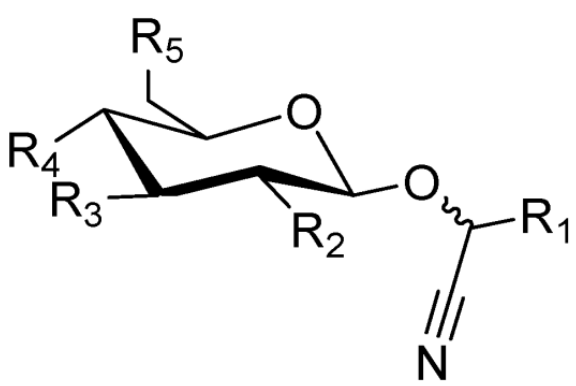

Figure 1 General structure of cyanogenic glycoside (Yulvianti and Zidorn, 2021).

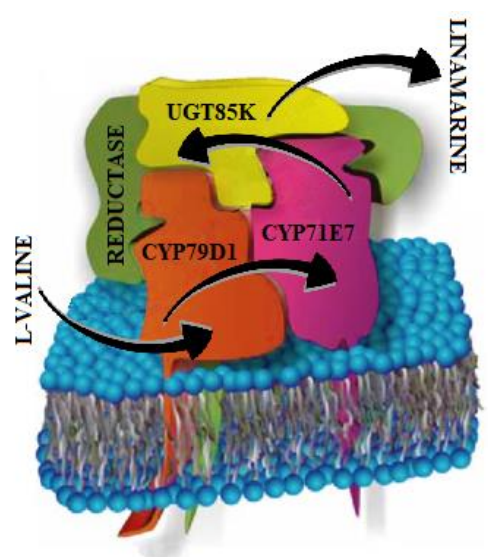

Figure 2 Metabolon responsible for linamarin synthesis from (Yulvianti and Zidorn, 2021). L-valine in flax (Bak et al., 2006, modified by Harenčár).

\section{Synthesis of cyanogenic glycosides}

Cyanogenic glycosides in plant are derivatives of five amino acids (L-valine, Lisoleucine, L-leucine, L-phenylalanine, and L-tyrosine) and the non-proteinogenic amino acid cyclopentenyl glycine (Nyirenda, 2020) (Table 1). The most represented cyanogenic glycosides in flax (Linum usitatissimum L.) are linamarin and lotaustralin with their diglucosidic forms linustatin and neolinustatin (Zuk $\boldsymbol{e}$ al., 2020). The biosynthetic pathways of these two respectively four secondary metabolites (Figure 3) are quite similar and initiated by N-hydroxylations of Lvaline (linamarin) or L-isoleucine in case of lotaustralin. This reaction can be done with use of the same valine or isoleucine N-monooxygenases e.g., CYP79D1, CYP79D2, CYP79D3, CYP79D4. The next step includes three different activities which are isomerization of the substrate (E) isomer ((E)-2-methylpropanal-oxime or (1E,2S)-2-methylbutanal oxime) to the (Z) isomer, dehydration, and C-hydroxylation by the same (E)-2-methylbutanal oxime monooxygenase (CYP71E7). The acetone cyanohydrin $\beta$ glucosyltransferase from family UGT85K provides the last step of the cyanogenic glucoside biosynthesis an attachment of the glucose coming from the UDP- $\alpha$-Dglucose. The diglucosidic forms linustatin and neolinustatin are created by an addition the second glucose with other UDP-glucosyltransferase (MetaCyc, 2021).

\section{CYANOGENIC GLYCOSIDES IN PLANT FOOD PRODUCTS}

The cyanide poisoning in humans is a serious health issue especially in the tropical regions where cassava or bamboo shoots are a primary nutritional staple (Panter, 2018). Cyanide inhibits a utilization of an oxygen and increases the anaerobic metabolism what lead to an excess of lactic acid and metabolic acidosis and finally to cell death through energy deprivation (Dusemund et al., 2017). The human body can tolerate a low level of HCN and converts it into the thiocyanate which is excreted in a urine (Grant, 2016). First clinical signs becoming evident within 30 minutes afterwards an ingestion of a toxic dose (Dalefield, 2017). Sublethal doses could lead to headache, hyperventilation, vomiting, weakness, abdominal cramps, and partial circulatory and respiratory systems failure (Castada et al., 2020). The toxic threshold value for cyanide in blood is considered to be between $0.5(\sim 20$ $\mu \mathrm{M})$ and $1.0 \mathrm{mg} . \mathrm{L}^{-1}(\sim 40 \mu \mathrm{M})$ and the lethal threshold value ranges between 2.5 $(\sim 100 \mu \mathrm{M})$ and $3.0 \mathrm{mg} . \mathrm{L}^{-1}(\sim 120 \mu \mathrm{M})$ (Schrenk et al., 2019). The acute lethal oral dose of cyanide is established in humans between 500 and $3500 \mu \mathrm{g} \cdot \mathrm{kg}^{-1}$ of body weight. Daily consumption of $20 \mu \mathrm{g}$ cyanide. $\mathrm{kg}^{-1}$ may cause chronic and $80 \mu \mathrm{g}$ $\mathrm{CN} . \mathrm{kg}^{-1}$ acute signs (Lindinger, 2019). Whereas these molecules are chemically quite stable in acidic and alkaline conditions the intermediate cyanohydrins $(\alpha-$ hydroxynitriles) are stable only in acidic media and spontaneously dissociate into the $\mathrm{CN}$ at neutral and alkaline $\mathrm{pH}$ (Schrenk et al., 2019).

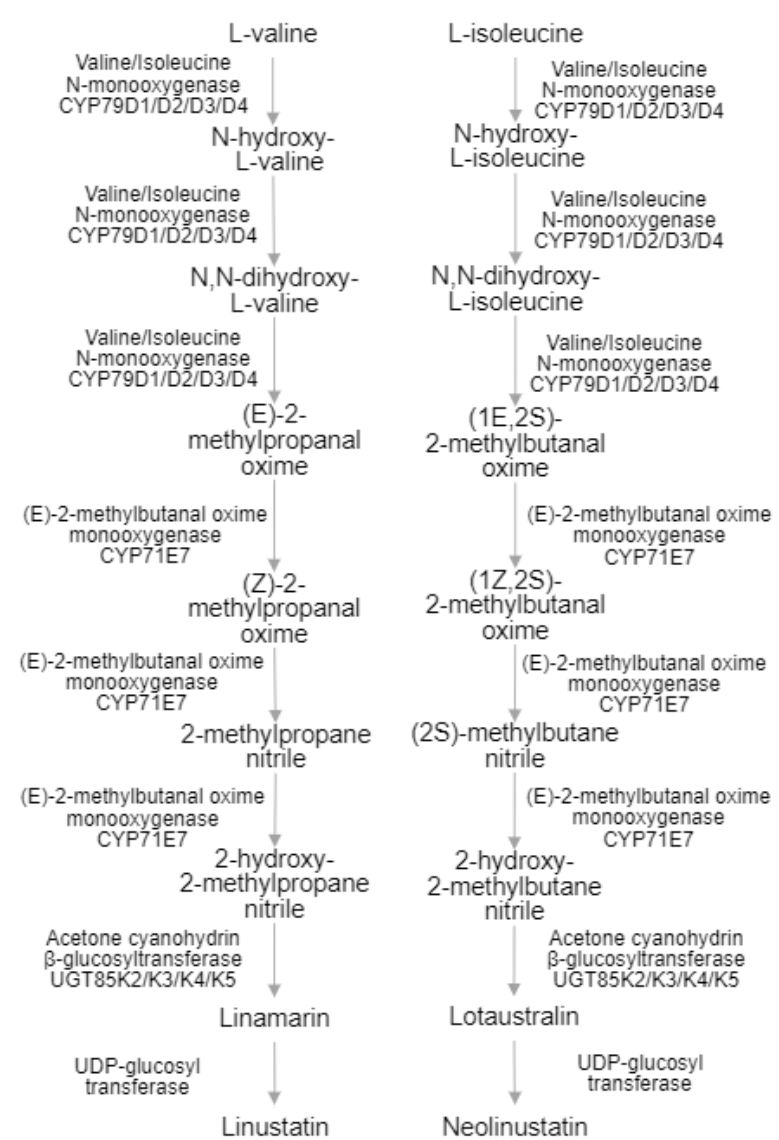

Figure 3 Biosynthetic pathway of cyanogenic glycosides, linustatin and neolinustatin in flax (elaborated by Harenčár).

The molecular bonds are hydrolyzed and catalyzed by a two-step enzymatic reaction utilizing $\beta$-glucosidases and hydroxy nitrile lyases. Both are synthesized by the same plant but stored in a different location. While the cyanogenic glycosides are stored in the vacuoles and mainly in leaf tissues, $\beta$-glucosidases are in the apoplastic space commonly attached to the cell walls, in the cytoplasm, vesicles or chloroplast and the hydroxy nitrile enzymes are accumulated in the cytoplasm (Vetter, 2017). The mammalian organisms have developed several metabolic pathways for the detoxification of the cyanide. About $70 \%$ of cyanide dose is metabolized in the presence of a sulfur donor thiosulfate and a sulfur transferase rhodanese into the thiocyanate which does not block an electron transport in the mitochondrial respiratory chain. High doses of thiocyanate may affect a thyroid function and goiter especially in an iodine deficiency (Eisenbrand and Gelbke, 2016). Cyanide can react also in another detoxification pathway with L-cystine through intermediate $\beta$-thiocyanoalanine to 2 -amino-2-thiazoline-4 carboxylic acid. The further detoxification pathway is the reaction of cyanide with an endogenous $\alpha$-ketoglutarate to form $\alpha$-ketoglutarate cyanohydrin or reaction with cysteine disulfide groups in serum albumin into a hydroxocobalamin (vitamin $\mathrm{B} 12 \mathrm{~b}$ ) or methaemoglobin. The complete hydrolysis of $1 \mathrm{~g}$ linamarin generates 109 $\mathrm{mg}$ of HCN and all mentioned metabolites are excreted in the urine (Schrenk $\boldsymbol{e t}$ al., 2019). The content of the cyanogenic glycosides in oil varieties of flaxseed planted in Czech Republic achieved the level from 1.9 to $5.5 \mathrm{~g} . \mathrm{kg}^{-1}$. The value of linamarin was in range of 0.05 to $0.2 \mathrm{~g} . \mathrm{kg}^{-1}$, linustatin 1.2 to $3.5 \mathrm{~g} . \mathrm{kg}^{-1}$ and neolinustatin of 0.6 to $2.2 \mathrm{~g} \cdot \mathrm{kg}^{-1}$ (Bjelková et al., 2017). Russo and Reggiani (2014) measured the total content of cyanogenic glycosides in flaxseed flour from 0.74 to $1.60 \mathrm{~g} . \mathrm{kg}^{-1} \mathrm{CN}^{-}$where oil varieties reached a higher value than fiber. Content of linamarin was ranged of 0.02 to $0.18 \mathrm{~g}^{\mathrm{kg}} \mathrm{kg}^{-1}$, linustatin 0.28 to $0.95 \mathrm{~g}$. $\mathrm{kg}^{-1}$ and neolinustatin from 0.06 to $0.85 \mathrm{~g} \cdot \mathrm{kg}^{-1}$. In the research of (Waszkowiak et al., 2015) the total content of $\mathrm{HCN}$ in hexane defatted flaxseed was approximately $0.3 \mathrm{~g} . \mathrm{kg}^{-1}$. The content of linamarin was $\sim 0.03 \mathrm{~g} . \mathrm{kg}^{-1}$, lotaustralin $\sim 0.04$ g. $\mathrm{kg}^{-1}$, linustatin $\sim 2.9 \mathrm{~g} . \mathrm{kg}^{-1}$ and neolinustatin $\sim 1.3 \mathrm{~g} \cdot \mathrm{kg}^{-1}$. Consuming of 30 grams flaxseed with a cyanogenic precursor content of $0.2 \mathrm{~g} \cdot \mathrm{kg}^{-1}$ seed will result in an average peak blood cyanide concentration of $5 \mu$ mole.L $L^{-1}$ (Abraham, Buhrke and Lampen, 2016). It is important to emphasize that one of the important factors influencing the content of CNG in flaxseed is genotype (Bjelková et al., 2017). Currently, the cyanogenic glycosides are still sold as an anticarcinogenic medicine (e.g., vitamin $\mathrm{B}_{17}$ - laetrile) in many countries whereas in the USA (where was this theory originated) it has been proven to be dangerous and ineffective in cancer treatment and all products have been withdrawn (Süli, Sobeková and Bujdošová,2017). 
Table 1 The overview of CNG by biochemical origin based KEGG database (https://www.genome.jp/kegg/, elaborated by Ražná)

\begin{tabular}{|c|c|c|}
\hline Biochemical origin of CNG & Type of CNG & Source \\
\hline \multirow[t]{7}{*}{ CNG derived from phenylalanine } & Amygdalin & $\begin{array}{l}\text { Prunus dulcis (Mill.) D. A. Webb, P. persica (L.) Batsch, } \\
\text { P. armeniaca L., P. avium (L.) L., Malus domestica Borkh. }\end{array}$ \\
\hline & Anthemis glycoside A & Anthemis altissima $\mathrm{L}$. \\
\hline & Anthemis glycoside B & Anthemis altissima $\mathrm{L}$. \\
\hline & Lucumin & Clerodendrum grayi Munir \\
\hline & Prunasin & Prunus sp. L., Olinia sp. Thunb., Senegalia greggii A.Gray \\
\hline & (R) - Vicianin & Vicia angustifolia $\mathrm{L}$. \\
\hline & Zierin & $\begin{array}{l}\text { Sambucus nigra L., Apis cerent, Xeranthemum inapertum (L.) } \\
\text { Mill., X. cylindraceum (L.) Mill. }\end{array}$ \\
\hline \multirow[t]{5}{*}{ CNG derived from thyrosine } & Dhurrin & Sorbus bicolor $\mathrm{L}$. \\
\hline & p-Glycosyloxymandelonitrile & Manihot esculenta Crantz, Bambusa sp. Schreb. \\
\hline & Proteacin & Lomatia sp. R.Br. \\
\hline & Taxiphyllin & Bambusa sp. Schreb. \\
\hline & Triglochinin & Araceae Juss. \\
\hline \multirow[t]{5}{*}{ CNG derived from valine or isoleucine } & Linamarin & \multirow{4}{*}{$\begin{array}{l}\text { Phaseolus lunatus } \mathrm{L} \text {. } \\
\text { Linum usitatissimum } \mathrm{L} \text {. } \\
\text { Manihot esculenta Crantz }\end{array}$} \\
\hline & Linustatin & \\
\hline & Lotaustralin & \\
\hline & Neolinustatin & \\
\hline & Sarmentosin & $\begin{array}{l}\text { Abraxas glossulariata L., Sedum stenopetalum Pursh., } \\
\text { Rhodiola sp. L., Piper sarmentosum Roxb. }\end{array}$ \\
\hline \multirow[t]{4}{*}{ CNG derived from leucine } & Cardiospermin & Cardiospermum halicacabum L. \\
\hline & Heterodendrin & Acacia sp. DC., Rhodiola sp. L., Vachellia sp. Wight \& $\underline{\text { Arn. }}$. \\
\hline & Proacaciberin & Acacia sieberiana DC. \\
\hline & Proacacipetalin & Acacia sieberiana DC. \\
\hline \multirow[t]{2}{*}{ CNG derived from nonprotein amino acid } & Deidaclin & $\begin{array}{l}\text { Passiflora sp. L., Turnera sp. L., Adenia globosa Engl., } \\
\text { Kiggelaria africana L. }\end{array}$ \\
\hline & Gynocardin & Baileyoxylon lanceolatum C.T.White, Achariaceae Harms \\
\hline CNG derived from other origin & Acalyphin & Acalypha indica $\mathrm{L}$. \\
\hline \multirow[t]{2}{*}{ Others } & Cycasin & Cycas revoluta Dumort, Zamia pumila L. \\
\hline & Ranunculin & Ranunculaceae Juss. \\
\hline
\end{tabular}

Legend: $\mathrm{CNG}$ - cyanogenic glycosides

\section{Processing approaches for CNG reduction content in plant food resources}

The risk of poisoning within many other plants consumed by humans is negligible due to very easy removing the toxic HCN from food by grinding, drying in air, soaking in water or other thermal treatment that in combination with effective human detoxifying mechanisms contributes to the denaturation of enzymes (Kudłak, Wieczerzak and Namieśnik, 2017).

Hydrogen cyanide is released from CNG-containing foods during food digestion or digestion, which hydrolyzes these substances. The aim of individual processes of processing plant food resources is to reduce the content of hydrogen cyanide $(\mathrm{HCN})$ to an acceptable safe level. Such processes are fermentation, boiling, cooking, drying (oven drying, freeze drying), grinding, soaking, peeling, roasting (Bolarinwa et al., 2016; Chongtham et al., 2021). The list of plant species containing CNG mainly in seeds/stones includes apples, apricots, cherries, peaches, plums, quinces, almonds, cassava, bamboo shoots, flaxseed, lima beans, chickpeas, cashews, but also food marzipan ingredients, alcoholic beverages from stone fruit (Bolarinwa et al., 2016) (Table 2). Fermentation has proven to be the most suitable method of processing bamboo shoots in terms of reducing $\mathrm{CNG}$ content (Chongtham et al., 2021).

Development of extraction methodology for cyanogenic glycosides is focused on identification and optimization of methods of disturbing the integrity of the tissue (e.g., seeds), extraction solvent composition, extraction time, repeat extraction and other factors (Barthet and Bacala, 2010). After extraction of cyanogenic glycosides from flaxseed, where the extraction efficiency was almost $88 \%$ for linustatin and neolinustatin, the ground flaxseed was stable up to 7 day at room temperature, refrigeration or freezing, and frozen for at least 2 weeks. Extracts of CNG were stable for 1 week at room temperature and at least 2 weeks under $4^{\circ} \mathrm{C}$ or frozen.

There are approaches based on bacteria-based degradation of cyanogenic glycosides in plant food resources. Menom et al. (2015) identified lactic acid bacteria capable of amygdalin degradation. Amygdalin fermentation by strains from Lactobacillus plantarum group represent a potential approach to biodetoxification of amygdalin for food improvement and safety. Seven strains of L. plantarum showed great variation in the ability to degrade amygdalin, linamarin, linustatin and neolinustatin. This was also the case of another tested strains of Candida tropicalis (Lei et al., 1999). Also, Bacillus species were screening for their ability to degrade linamarin in cassava and amygdalin (Abban et al., 2013). As study showed, some Bacillus spp. isolates (B. subtilis, B. licheniformis and B. sonorensis) can hydrolyze $\mathrm{CNG}$ during cassava fermentation at $\mathrm{pH}$ 4.5-5.0. Research results suggest that, co-culture of the most active strains regarding betaglucosidase activity, seem to degrade linamarin faster than the monoculture (Lei et al., 1999).

\section{Antimicrobial activity of CNG}

Amygdalin from crushed apple seeds has shown the ability to inhibit the growth of two Gram-positive species (Staphylococcus aureus and Streptococcus pyogenes) and two Gram-negative species (Escherichia coli and Pseudomonas aeruginosa) pathogenic bacteria. The zone of activity inhibition was highlighted with increasing concentration of undiluted extract (Mhawesh et al., 2018).

The hot apricot seed extract significantly inhibited the growth of the tested bacterial strains, of which Staphylococcus aureus showed the highest sensitivity. The highest antibacterial substance was shown by the aqueous extract of apricot seeds (Abtahi et al., 2008).

Citrus lanatus seed extract containing cyanogenic glycosides showed antibacterial activity against Staphylococcus aureus, Klebsiella pneumoniae, Escherichia coli, Pseudomonas aeruginosa, Bacillus cereus, Proteus mirabilis and Streptococcus pyogenes (Nwankwo et al. 2014). Phytochemcal screening of inner bark of Atuna racemosa reveals the presence of several secondary metabolites including cyanogenic glycosides which showed antimicrobial activity against Bacillus subtilis, Staphylococcus aureus, Escherichia coli, Klebsiella pneumoniae, Salmonella typhimurium, and Pseudomonas aeruginosa (Nadayag et al., 2019). Antibacterial, antifungal and antiparasitic activities of extracts of Mexican medicinal plant Laennecia confusa of Asteraceae family were confirmed. Extracts including cyanogenic and cardiotonic glycosides demonstrated antibacterial activity against Staphylococcus aureus and antiparasitic activity against Leishmania donovani and were also found to be cytotoxic to macrophages (Martinez Ruiz et al., 2012).

The oils extracted from seeds of Brassica nigra and Cucurbita pepo showed antibacterial activities on fresh hospital isolates Staphylococcus aureus and Escherischia coli. A higher zone of inhibition of $60 \%$ on S. aureus were produced by oil from C. pepo whose phytochemical analyses revealed the content of tannins, flavonoids, saponins, cyanogenic glycosides and cardiac glycosides, while the oil from B. nigra does not consists cyanogenic glycosides and showed lower inhibitory effect on S. aureus. However, both oil extracts showed similar inhibitory effects on E. coli (Obi et al., 2009).

Nwaogu et al. (2008) conducted the antimicrobial screening of leaf and root extracts from Landolphia owariensis against clinical isolates of Staphylococcus spp., Proteus spp. and Escherichia coli. The phytochemical screening indicated the presence of cyanogenic glycosides only in root extract. Although, the response of tested strains to extracts was concentration dependent, dehydrogenase activity was inhibited by the root extract at a higher concentration range than the leaf extract. 


\section{THE ROLE OF CYANOGENIC GLYCOSIDES IN PLANTS}

Plants produce many phytochemicals and metabolites enabling interactions with their biotic and abiotic environment (Thodberg et al., 2020). Release of hydrogen cyanide makes an effective chemical defense against generalist herbivores and pathogens (Hansen et al., 2018). Many authors termed this defense ability as a cyanide bomb (Yeats, 2018). The ability to synthetize cyanogenic glycosides is at least 300 million years old and distributed among 130 families in pteridophytes (ferns), gymnosperms and angiosperms (flowering plants) (Van Ohlen, Herfurth and Wittstock, 2017). Ferns and gymnosperm species contain aromatic cyanogenic glycosides derived from either tyrosine or phenylalanine whereas angiosperms contain aliphatic as well as aromatic cyanogenic glycosides derived from valine, leucine, isoleucine or tyrosine and phenylalanine, respectively. Few plants species such as passiflora contain cyanogenic glycosides derived from the non-protein amino acid cyclopentenyl glycine (Bak et al., 2006). This fact indicates that the cyanogenic glycosides were initially only aromatic and afterwards aliphatic (Mobot, 2021). The functions of cyanogenic glycosides and hydrogen cyanamide lie in the expression of floral regulative, antioxidant and hypoxia-responsive genes and catalase activity. In the buds influence the level of hydrogen peroxide, calcium, ethylene, proline putrescine and phytohormones, buds opening and seed germination (Nielsen et al., 2016; Ionescu et al., 2017) The other potential physiological functions are elimination of reactive oxygen and osmoprotective function associated with tolerance to abiotic stresses including drought, salt, temperature, and oxidative and nutrient stresses (Hayes et al., 2015) The plants have developed the endogenous turnover pathways enabling utilization of nitrogen as ammonia without any release of hydrogen cyanide and detoxification pathway to avoid hydrogen cyanide intoxication in which $\beta$-cyanoalanine synthase catalyzes the conversion of hydrogen cyanide into $\beta$-cyanoalanine. In subsequent reaction is hydration of $\beta$-cyanoalanine catalyzed by type 4 nitrilase resulting in the production of asparagine or aspartate and ammonia (Del Cueto et al., 2017) The followed figure 4 displays different functions of cyanogenic glycosides in plants. The investigation of the role of CNG in plants has been part of several research projects (Table 2).

Table 2 Overview of some of the research intentions of the importance of CNG in the species consumed (elaborated by Ražná)

\begin{tabular}{|c|c|c|c|c|c|}
\hline Species & Name & Tissue type & Type of CNG & The purpose of the investigation & Reference \\
\hline Hordeum vulgare $\mathrm{L}$. & Barley & $\begin{array}{l}\text { Seeds, roots, } \\
\text { seedlings }\end{array}$ & & $\begin{array}{l}\text { The role of CNG as nitrogen storage } \\
\text { compounds }\end{array}$ & Forslund and Jonsson, 2006 \\
\hline Linum usitatissimum $\mathrm{L}$. & Flax & Linseed & $\begin{array}{c}\text { Linustatin } \\
\text { Neolinustatin }\end{array}$ & CNG validation in agri-food & Zhong et al., 2020 \\
\hline Malus domestica Borkh. & Apple & Apple seeds & $\begin{array}{l}\text { Cyanogenic } \\
\text { glycosides }\end{array}$ & $\begin{array}{c}\text { Environmental conditions, long term } \\
\text { storage effect }\end{array}$ & Senica et al., 2019 \\
\hline Phaseolus lunatus $\mathrm{L}$. & Lima Bean & $\begin{array}{c}\text { Seeds, seedlings } \\
\text { leaves }\end{array}$ & Linamarin & The role in defense or plant nutrition & Cuny et al., 2019 \\
\hline \multirow[t]{2}{*}{ Prunus armeniaca $\mathrm{L}$. } & \multirow[t]{2}{*}{ Apricot } & \multirow[t]{2}{*}{ Fruit, kernel } & \multirow[t]{2}{*}{$\begin{array}{l}\text { Prunasin, } \\
\text { Amygdalin }\end{array}$} & $\begin{array}{l}\text { Accumulation pattern and fruit } \\
\text { parameters }\end{array}$ & Deng et al., 2021 \\
\hline & & & & CNG validation in agri-food & Zhong et al., 2020 \\
\hline Prunus avium (L.) L. & $\begin{array}{l}\text { Sweet } \\
\text { Cherry }\end{array}$ & Flower buds & $\begin{array}{l}\text { Prunasin, } \\
\text { Amygdalin }\end{array}$ & $\begin{array}{l}\text { Controlling flower development and } \\
\text { dormancy }\end{array}$ & Del Cueto et al., 2017 \\
\hline \multirow{2}{*}{ Prunus dulcis (Mill.) D. A. Webb } & \multirow{2}{*}{ Almond } & \multirow{2}{*}{$\begin{array}{l}\text { Flower buds, } \\
\text { roots, leaves, } \\
\text { kernels }\end{array}$} & \multirow{2}{*}{$\begin{array}{l}\text { Prunasin, } \\
\text { Amygdalin }\end{array}$} & $\begin{array}{l}\text { Controlling flower development, } \\
\text { dormancy }\end{array}$ & Del Cueto et al., 2017 \\
\hline & & & & Intraspecific variability & Dicenta et al., 2002 \\
\hline Sambucus canadensis $\mathrm{L}$. & $\begin{array}{l}\text { American } \\
\text { Elderberry }\end{array}$ & $\begin{array}{c}\text { Fruit tissues, } \\
\text { pressed juice } \\
\text { samples, seeds }\end{array}$ & $\begin{array}{l}\text { Total cyanogenic } \\
\text { potential }\end{array}$ & Potential toxicity issues & Appenteng et al., 2021 \\
\hline Sorghum bicolor $($ L.) Moench & Sorghum & Sorghum rice & Dhurrin & CNG validation in agri-food & Zhong et al., 2020 \\
\hline Vitis vinifera $L$. & Grapevine & Mature leaves & $\begin{array}{c}\text { Prunasin } \\
\text { Sambunigrin }\end{array}$ & $\begin{array}{c}\text { Polymorphism and developmental } \\
\text { pattern }\end{array}$ & Franks et al., 2004 \\
\hline
\end{tabular}

Legend: $\mathrm{CNG}$ - cyanogenic glycosides

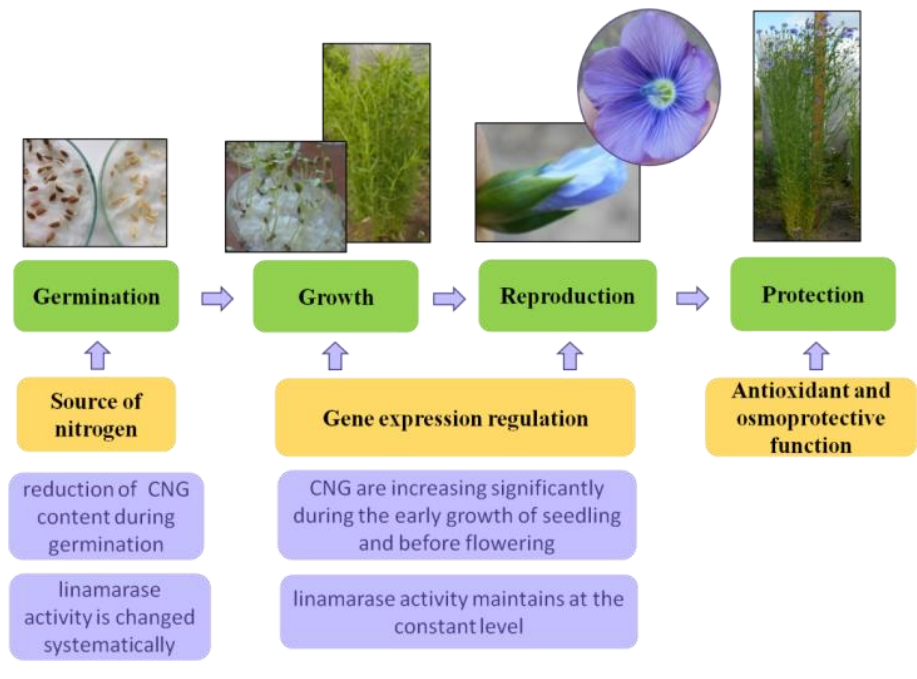

Figure 4. A summary of CNG functions in plants (photo by Ražná and Hlavačková)

\section{Representation of CNG in individual parts of the flax plant}

Flax is one of the most frequently used sources of food products and nutritional supplements and is also a crop to which intensive attention is paid to the overall importance of cyanogenic glycosides. The potential concentration of $\mathrm{HCN}$ in various parts of flax may be differ and depends on a location and year of production whereas the most important factor is a cultivar (Oomah, Mazza, and Kenaschuk, 2002). Large amount of cyanogenic glycosides accumulates in the seed, young seedlings, leaves, growing shoot and flowers (Siegień, 2007). Plant seed germination causes de novo synthesis of bioactive phytochemicals such as ascorbic acid, phenylic acids, flavonoids, free and poly amino acids. On the other hand, in flaxseed was observed a reduced content of oil, cyanogenic glycosides and trypsin inhibitor during 8 days of germination (Wang et al., 2016). In another research, on the 5th day the content of linustatin, neolinustatin and lotaustralin significantly decreased however the content of linamarin was higher (Li et al., 2019). In other 5-days oil seedlings, depending on a higher intensity and longer exposure time of a white light with the highest temperature $30^{\circ} \mathrm{C}$ the cyanogenic glucosides content was enhanced. An enzyme activity of linamarase was the highest at $20^{\circ} \mathrm{C}$, especially in light-grown seedlings and the lowest in extreme 15 and $30^{\circ} \mathrm{C}$ temperature. Water stress reduced the cyanogenic glucoside level and linamarase activity by more than twice (Niedźwiedź-Siegień and Gierasimiuk, 2001). The cyanogenic diglucosides linustatin and neolinustatin are the main in developing embryos and mature seed. After germination are rapidly depleted and the monoglucosides linamarin and lotaustralin were also found in leaves, flowers and developing embryos. Roots and stems contained relatively low concentrations of cyanogenic glucosides (Muir and Westcott, 2003). High levels of linamarin and lotaustralin were found in leaves throughout the vegetation period, but the highest amounts were in flowers (Niedźwiedź-Siegień, 1998). The total content of cyanoglycosides increases significantly during the early growth of seedlings and before flowering (Adamczuk, Siegień, and Ciereszko, 2015). The flaxseed content of $\mathrm{HCN}$ in period from anthesis (0 days after flowering) to maturity (40 DAF) was on the decrease from 2-3 mmol HCN to 0.4-1.3 mmol.dm ${ }^{-3}$ (Figure 4). A broad maximum of $\mathrm{HCN}$ per flax fruit appeared between 7 and $18 \mathrm{DAF}$ and was characterized by a high variability among the samples. A ratio between monoglycosides and diglucosides was shifted from $100 \%$ monoglycosides at anthesis (0-18 DAF) to $100 \%$ diglucosides at maturity (25-40 DAF). The monoglucosides linamarin and lotaustralin produced in parental tissues of the flax plant would be translocated into the growing seeds as the corresponding diglucosides linustatin and neolinustatin which persist in the seed until the seed will be germinated (Frehner, Scalet and Conn, 1990). The presence of forms of 
CNG in the various development stages and plant parts of flax is shown in Figure

An integrated approach to the identification of the formation and deposition of cyanogenic glycosides in the seed tissues of flaxseed has made it possible to localize these components in the germ layer (ovaries), in the endosperm and in the embryo. In contrast to the lignans that are part of the seed coat (Dalisay $\boldsymbol{e t}$ al. 2015).

Seedling derived and regenerated in vitro shoots from hypocotyl showed about twice higher accumulation of linamarin and lotaustralin in light conditions. The low content of these compounds in roots was unchanged regardless of light conditions. Tiny quantity was also detected in callus tissue, but only under light conditions (Siegień, Adamczuk and Wróblewska, 2013). The content of cyanogenic compound is positively correlated with amount of protein in the seed and the level of nitrogen fertilization. The lower nitrogen supply can keep the content of cyanogenic glycosides at the required level (Klein et al., 2017).
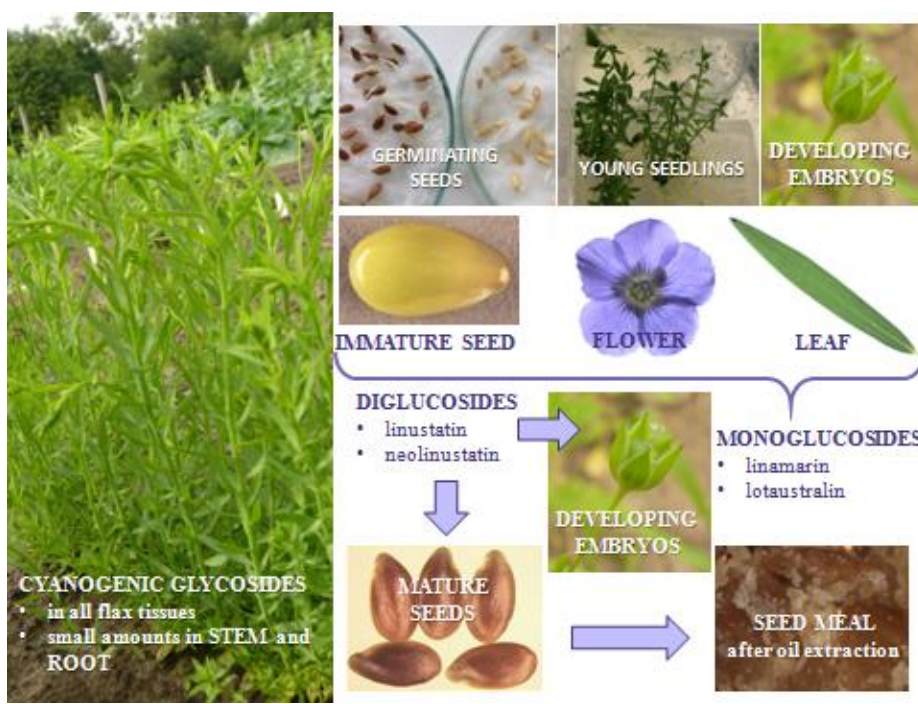

Figure 5 The presence of forms of CNG in the various development stages and plant parts of flax (photo by Nôžková).

\section{CNG as part of plant defense mechanism}

Secondary metabolites in plant species fulfill specific functions, such as attracting insects to transfer pollen, animals to eat the fruits and and subsequent pollen transfer; and they can act as natural pesticides. They can protect the plants from pathogenic microorganisms and herbivores. These defending substances are permanently the part of the plants (Heldt and Heldt, 2005). Very effective defense system is formed in plants because the presence of two different toxic substances. When the cell is injured by feeding animals, the glycosidase encounters cyanogenic glycosides. The remaining substance of glucose residue hydrolysis is cyanhydrin. It is very unstable, and it is degraded spontaneously to prussic acid and an aldehyde. The detoxification of the aldehydes, which are usually very toxic, is even more difficult for feeding animals than that of prussic acid. The prussic acid ( $\mathrm{HCN})$ is also very toxic, and it inhibits cytochrome oxidase, which is final step of the respiratory chain. The plants are protecting themselves by the fact that the prussic acid is in the bound form as cyanogenic glycosides because they have a mitochondrial respiratory chain also. Decomposition to the prussic acid and aldehydes is accelerating by enzyme a hydroxynitrile lyase (Heldt and Heldt, 2005; Ballhorn, 2011).

Cyanogenic glycosides and their corresponding degrading enzymes ( $\beta$ glucosidases; hydroxynitrile lyases) are part of a preformed defense system. Thus, they can be regarded as phytoanticipins (Pičmanová et al., 2015). Some insects are strongly associated with their cyanogenic host plants. They sequester the cyanogenic glycosides from these pants as well as carry out de novo biosynthesis of these compounds. Contrary to phytoalexins that are synthesized de novo after the plant is exposed to microbial attack, i.e., being produced in response of elicitors or stressors, the phytoanticipins are not formed in the tissue or released from preexisting plant constituents. These substances are plant antibiotics presented in tissue prior to infection, serving as the basis of pest tolerance (Oros and Kállai, 2019).

Cyanide production in leaves has role to herbivore defense, but ecological function of cyanogenic precursor in seeds is still not entirely clear. One option may be that during seed germination these compounds are transferred to the growing seedling for their defense, and in addition cyanogenic glycosides can store nitrogen that is required for seedling grow, or they can act as germination inhibitors (Ballhorn, 2011).
It is believed that by hydrolysis of CNGs during seed germination, they are thought to be used as a nitrogen source for amino acid synthesis and, at the same time, the released hydrogen cyanide $(\mathrm{HCN})$ performs a protective function of germs against pests (Krech and Fieldes, 2003). The process of cyanogenesis leads to serious problems for feeding animals while cyanogenic glycosides as defensive secondary metabolites play important roles in plant development and response to adverse environment (Pičmanová et al., 2015).

In the genus Phaseolus, the only species in which the content of cyanogenic glycosides has been recorded is lima bean (Phaseolus lunatus L.). The cyanogenic glycosides contained in the seeds of this species are related to the defense mechanisms of the seedlings against the leaf pest (Spodoptera littoralis), but do not have a negative effect on germination and further growth. The results confirmed that seeds with a higher CNG content provide better protection of the primary leaves of seedlings and point to their defensive rather than nutritional role in the seeds. The authors observed a demonstrable positive correlation between CNG content, defined by the level of linamarin ( $\left.\mathrm{mg} \cdot \mathrm{g}^{-1}\right)$, in seeds and CNG content in cotyledones of seedlings. However, no significant correlation was observed between $\mathrm{CNG}$ content in seeds and in primary and secondary leaves. The level of linamarin in germinating seeds increased by $100 \%$ compared to seed and by $230 \%$ when comparing the level of linamarin between germinating seeds and young seedlings (Cuny et al., 2019).

During germination, the content of neolinustatin was higher in the seeds and the content of lotaustralin was higher recorded in the cotyledons of the seedlings. However, the distribution of CNG did not support the assumption that the content of these components in the hypocotyl is responsible for the protection of seedlings against soil pests. In flax as well as other cyanogenic plants, HCN, as a product of CNG hydrolysis, is expected to play a much more important role in regulating seed germination and prolonged growth of germline hypocotyl than as a potential nitrogen source for amino acid synthesis by mediating ethylene production to help overcome dormancy of seeds and stimulates growth. The activity profile of linamarin-cleaving linamarase and lotaustralin points to its role during the early stages of germination and during cotyledon expansion. In young flax seedlings, linamarase activity is stable (Fieldes and Gerhardt, 2001).

\section{The role of CNG in environmental adaptation of plants}

Plants that produce hydrogen cyanide $(\mathrm{HCN})$ are an important part of the human diet. All plants produce small amounts $\mathrm{HCN}$ as a by-product of ethylene biosynthesis. However, some plant species can release large amounts of hydrogen cyanide from endogenous secondary metabolites - cyanogenic glycosides (Gleadow and Møller, 2014). Genetic conditionality and heredity of cyanogenesis are governed by Mendelian patterns of heredity, but its quantitative expression is very plastic depending on the tissue or growth phase. Elevated concentrations of hydrogen cyanide have been reported in connection with adverse environmental conditions, such as lack of light, low temperatures and drought, as well as lack of soil moisture (Gleadow and Møller, 2014). Accumulation of high concentrations of dhurrin in sorghum plants was confirmed during drought stress (O'Donnell $\boldsymbol{e t}$ al., 2013).

It has been shown that environmental stress result in decrease in oil content in flax. However, significant changes in the content of cyanogenic glycoside in flaxseed under different environmental stress were confirmed together with significant varietal differences in CNG content (Daun and Przybylski, 2000).

The polymorphism of cyanogenic glycosides is subject to specific environmental conditions and plant ontogenesis (Figure 6). CNGs improve phenotypic plasticity by increasing the ability of plants to adapt to changing environmental conditions. Given the high proportion of foods derived from cyanogenic crops, it will be important to predict the response of the genome of these species to environmental changes in the context of food safety (Gleadow and Moller, 2014).

The mandelonitrile which is part of cyanogenic glycoside biosynthesis was tested in peach plant response to abiotic and biotic stress factors (salt and virus infection) (Bernal-Vicente et al., 2018). The study showed reduced impact of both stresses on plant development of mandelonitrile treated seedlings.

Cyanide potential of sorghum depends on genotype, environmental factors, and crop management (Emendack et al., 2018). Different (40) sorghum lines were tested on dhurrin content in leaves under water deficit stress. The lines (5) with very low dhurrin content were identified across developmental stages a water deficit stress. In general, younger plants (30 days old) content less cyanogenic glycoside - dhurrin than older ones. Water stress applied shortly just before flowering manifested itself in a reduction of dhurrin in leaves, while the same stress applied in post-flowering phase caused an increase of dhurrin.

The study of diurnal regulation of cyanogenic glycosides in cassava showed that linamarin content increased during the dark period and on other side the light period caused rapid decrease in linamarin content suggesting its additional role in anti-oxidative stress as a ROS scavenger (Schmidt et al., 2018). In silico analyses of promoter sequences of genes involved in CNG biosynthesis revealed a presence of light, abiotic stress and development-related transcription factor binding motifs. Similarly, the presence of cyanogenic glycoside - dhurin in sorghum supports its role in reducing oxidative stress (O'Donnell et al., 2013). 
effect changing over time and conditions

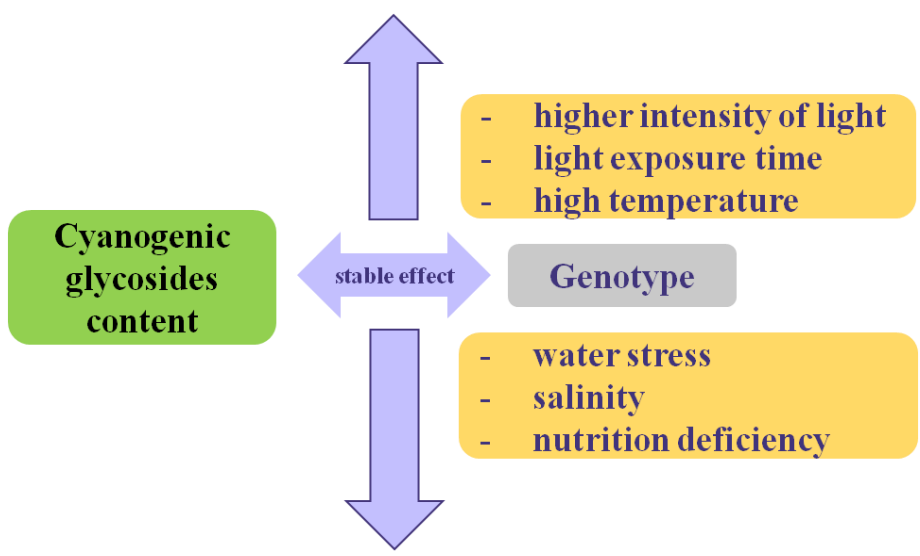

Figure 6 Factors affecting the metabolism activity of cyanogenic glycosides

\section{CONCLUSION}

The growing trend of searching for alternative food sources is conditioned on the one hand by the increasing interest of people in the quality of nutrition, but also by the growing incidence of nutrition-related diseases. the presence of secondary metabolites in plants is justified and it is therefore important to perceive their importance in the context of the functioning of the whole organism. From this poin of view, it is necessary to find a new potential of secondary metabolites for nutrition and food use. Plant cyanogenic glycosides represent naturally occurring phytotoxins, secondary metabolites produced by plant biochemical machinery as part of various defense, nutritional and adaptive processes. Cyanogenic glycosides can be beneficial in many applications (a) to agriculture for development of biobased agents in plant protection, (b) to plant adaptation potential against enviro stress and (c) for health and hygiene requirements (antimicrobial properties). The identification of added value of plant food resources is closely connected with the knowledge of the overall metabolism of plants and the role of individual components in the harmonious context of the plant organism.

Acknowledgments: This publication was supported by the Operational Program Integrated Infrastructure within the project: Demand-driven research for the sustainable and innovative food, Drive4SIFood 313011V336 and Operational Program Integrated Infrastructure for the project: Long-term strategic research of prevention, intervention and mechanisms of obesity and its comorbidities, IMTS: 313011V344, co-financed by the European Regional Development Fund.

\section{REFERENCES}

Abban, S., Brimer, L., Abdelgadir, W.S. et al. (2013). Screening for Bacillus subtilis group isolates that degrade cyanogens at $\mathrm{pH}$ 4.5-5.0. International Journal of Food Microbiology. 161(1), 31-35. doi: https://doi.org/10.1016/j.ijfoodmicro.2012.11.019

Abraham, K., Buhrke, T., \& Lampen, A. (2015). Bioavailability of cyanide after consumption of a single meal of foods containing high levels of cyanogenic glycosides: a crossover study in humans. Archives of Toxicology, 90(3), 559-574. doi: https://doi.org/10.1007/s00204-015-1479-8

Abtahi, H., Ghazavi, A., Karimi, M., Mollaghase, S., \& Mosayebi, G. (2008) Antimicrobial Activities of Water and Methanol Extracts of Bitter Apricot Seeds. Journal of Medical Sciences, 8(4), 433-436. doi: https://doi.org/10.3923/jms.2008.433.436

Adamczuk, A., Siegień, I., \& Ciereszko, I. (2015). Len zwyczajny (Linum usitatissimumL.). Edukacja Biologiczna i Środowiskowa, 3, 15-21. http://ebis.ibe.edu.pl/numery/2015-3/ebis-2015-3-3.pdf

Alzahrani, A. M., \& Rajendran, P. (2020). The Multifarious Link between Cytochrome P450s and Cancer. Oxidative Medicine and Cellular Longevity, 2020, 1-18. doi: https://doi.org/10.1155/2020/3028387

Appenteng, M. K., Krueger, R., Johnson, M. C., Ingold, H., Bell, R., Thomas, A. L., \& Greenlief, C. M. (2021). Cyanogenic Glycoside Analysis in American Elderberry. $\quad$ Molecules, 26(5), $1384 . \quad$ doi: https://doi.org/10.3390/molecules26051384

Bak, S., Paquette, S. M., Morant, M., Morant, A. V., Saito, S., Bjarnholt, N., ... Møller, B. L. (2006). Cyanogenic glycosides: a case study for evolution and application of cytochromes P450. Phytochemistry Reviews, 5(2-3), 309-329. doi: https://doi.org/10.1007/s11101-006-9033-1

Ballhorn, D. J. (2011). Cyanogenic Glycosides in Nuts and Seeds. Nuts and Seeds in Health and Disease Prevention, 129-136. doi: https://doi.org/10.1016/b978-012-375688-6.10014-3
Barthet, V. J., \& Bacala, R. (2010). Development of Optimized Extraction Methodology for Cyanogenic Glycosides from Flaxseed (Linum usitatissimum). Journal of AOAC INTERNATIONAL, 93(2), 478-484. doi: https://doi.org/10.1093/jaoac/93.2.478

Bassard, J.-E., Møller, B. L., \& Laursen, T. (2017). Assembly of Dynamic P450Mediated Metabolons - Order Versus Chaos. Current Molecular Biology Reports, 3(1), 37-51. doi: https://doi.org/10.1007/s40610-017-0053-y

Bernal-Vicente, A., Cantabella, D., Hernandez, J. A. et al. (2018). The effect of mandelonitrile, a recently described salicylic acid precursor, on peach plan response against abiotic and biotic stresses. Plant Biology, 20(6), 986-994. doi: https://doi.org/10.1111/plb.12894

Bjelková, M., Filip, V., Kyselka, J., Ševčík, R., \& Větrovcová, M. (2017). Výběr a charakteristika Iněného semene jako vstupní suroviny. https://www.agritec.cz/sites/default/files/978-80-87360-57-6.pdf

Bolarinwa, I. F., Oke, M. O., Olaniyan, S. A., \& Ajala, A. S. (2016). A Review of Cyanogenic Glycosides in Edible Plants. Toxicology - New Aspects to This Scientific Conundrum. doi: https://doi.org/10.5772/64886

Castada, H. Z., Liu, J., Ann Barringer, S., \& Huang, X. (2020). Cyanogenesis in Macadamia and Direct Analysis of Hydrogen Cyanide in Macadamia Flowers, Leaves, Husks, and Nuts Using Selected Ion Flow Tube-Mass Spectrometry. Foods, 9(2), 174. doi: https://doi.org/10.3390/foods9020174

Cuny, M.A.C., La Forgia, D., Desurmont, G.A., Glauser, G., Benrey, B. (2019). Role of cyanogenic glycosides in the seeds of wild lima bean, Phaseolus lunatus: defense, plant nutrition or both? Planta, 250. 1281-1292. doi https://doi.org/10.1007/s00425-019-03221-3

Dalefield, R. (2017). Poisonous Plants. Veterinary Toxicology for Australia and New Zealand, 485-572. doi: https://doi.org/10.1016/b978-0-12-420227-6.00023 2

Dalisay, D. S., Kim, K. W., Lee, C., Yang, H., Rübel, O., Bowen, B. P., ... Lewis, N. G. (2015). Dirigent Protein-Mediated Lignan and Cyanogenic Glucoside Formation in Flax Seed: Integrated Omics and MALDI Mass Spectrometry Imaging. Journal of Natural Products, 78(6), 1231-1242. doi https://doi.org/10.1021/acs.jnatprod.5b00023

Daun, J.K., Przybylski, R. (2000). Environmental effects on the composition of four Canadian flax cultivars. Proceedings of the 58th Flax Institute of The United States,91-80

Del Cueto, Jorge, Irina A. Ionescu, Martina Pičmanová, Oliver Gericke, Mohammed S. Motawia, Carl E. Olsen, José A. Campoy, Federico Dicenta, Birger L. Møller, and Raquel Sánchez-Pérez. "Cyanogenic Glucosides and Derivatives in Almond and Sweet Cherry Flower Buds from Dormancy to Flowering." Frontiers in Plant Science 8 (May 19, 2017). doi: https://doi.org/10.3389/fpls.2017.00800 Deng, P., Cui, B., Zhu, H., Phommakoun, B., Zhang, D., Li, Y., ... Zhao, Z. (2021). Accumulation Pattern of Amygdalin and Prunasin and Its Correlation with Fruit and Kernel Agronomic Characteristics during Apricot (Prunus armeniaca L.) Kernel Development. Foods, 10(2), 397. doi: https://doi.org/10.3390/foods10020397

Dicenta, F., Martínez-Gómez, P., Grané, N., Martín, M. L., León, A., Cánovas, J. A., \& Berenguer, V. (2002). Relationship between Cyanogenic Compounds in Kernels, Leaves, and Roots of Sweet and Bitter Kernelled Almonds. Journal of Agricultural and Food Chemistry, 50(7), 2149-2152. doi: https://doi.org/10.1021/jf0113070

Duodu, K. G., \& Apea-Bah, F. B. (2017). African Legumes: Nutritional and Health-Promoting Attributes. Gluten-Free Ancient Grains, 223-269. doi: https://doi.org/10.1016/b978-0-08-100866-9.00009-1

Dusemund, B., Rietjens, I. M. C. M., Abraham, K., Cartus, A., \& Schrenk, D. (2017). Undesired Plant-Derived Components in Food. Chemical Contaminants and Residues in Food, 379-424. doi: https://doi.org/10.1016/b978-0-08-100674$\underline{0.00016-3}$

Eisenbrand, G., \& Gelbke, H.-P. (2016). Assessing the potential impact on the thyroid axis of environmentally relevant food constituents/contaminants in humans. Archives of Toxicology, 90(8), 1841-1857. doi: https://doi.org/10.1007/s00204-016-1735-6

Emendack, Y., Burke, J., Laza, H. et al. (2018). Abiotic Stress Effects on Sorghum Leaf Dhurrin and Soluble Sugar Contents throughout Plant Development. Crop Science, 58(4), 1706-1716. doi: https://doi.org/10.2135/cropsci2018.01.0059

Fieldes, M. A., \& Gerhardt, K. E. (2001). Developmental and genetic regulation of ß-glucosidase (linamarase) activity in flax seedlings. Journal of Plant Physiology, 158(8), 977-989. doi: https://doi.org/10.1078/0176-1617-00301

Forslund, K., \& Jonsson, L. (1997). Cyanogenic glycosides and their metabolic enzymes in barley, in relation to nitrogen levels. Physiologia Plantarum, 101(2), 367-372. doi: https://doi.org/10.1111/j.1399-3054.1997.tb01010.x

Franks, T. K., Hayasaka, Y., Choimes, S., \& van Heeswijck, R. (2005) Cyanogenic glucosides in grapevine: polymorphism, identification and 
developmental patterns. Phytochemistry, 66(2), 165-173. doi https://doi.org/10.1016/j.phytochem.2004.11.017

Frehner, M., Scalet, M., \& Conn, E. E. (1990). Pattern of the Cyanide-Potential in Developing Fruits. Plant Physiology, 94(1), 28-34. doi: https://doi.org/10.1104/pp.94.1.28

Gleadow, R. M., \& Møller, B. L. (2014). Cyanogenic Glycosides: Synthesis, Physiology, and Phenotypic Plasticity. Annual Review of Plant Biology, 65(1), 155-185. doi: https://doi.org/10.1146/annurev-arplant-050213-040027

Grant, E. (2016). Attempted Quantification of the Cyanogenic Glycosides Prunasin and Sambunigrin in the Sambucus L.(Elderberry). Honors College. 389. https://digitalcommons.library.umaine.edu/honors/389

Griffing, L. R., Lin, C., Perico, C., White, R. R., \& Sparkes, I. (2016). Plant ER geometry and dynamics: biophysical and cytoskeletal control during growth and biotic response. Protoplasma, 254(1), 43-56. doi: https://doi.org/10.1007/s00709016-0945-3

Guigas, G., \& Weiss, M. (2016). Effects of protein crowding on membrane systems. Biochimica et Biophysica Acta (BBA) - Biomembranes, 1858(10), 2441 2450. doi: https://doi.org/10.1016/j.bbamem.2015.12.021

Hansen, C. C., Sørensen, M., Veiga, T. A. M., Zibrandtsen, J. F. S., Heskes, A. M., Olsen, C. E., Neilson, E. H. J. (2018). Reconfigured Cyanogenic Glucoside Biosynthesis in Eucalyptus cladocalyx Involves a Cytochrome P450 CYP706C55. Plant Physiology, 178(3), 1081-1095. doi: https://doi.org/10.1104/pp.18.00998 Hartanti, D., \& Cahyani, A. N. (2020). Plant cyanogenic glycosides: an overview. Farmasains: Jurnal Farmasi dan Ilmu Kesehatan, 5(1), 1-6.doi: https://doi.org/10.22219/farmasains.v5i1.10047

Hayes, C. M., Burow, G. B., Brown, P. J., Thurber, C., Xin, Z., \& Burke, J. J. (2015). Natural Variation in Synthesis and Catabolism Genes Influences Dhurrin Content in Sorghum. The Plant Genome, 8(2). doi: https://doi.org/10.3835/plantgenome2014.09.0048

Held, H.-W., \& Held, F. (2005) Plant Biochemistry. doi https://doi.org/10.1016/b978-0-12-088391-2.x5000-7

Chadha, R. K., Lawrence, J. F., \& Ratnayake, W. M. N. (1995). Ion chromatographic determination of cyanide released from flaxseed under autohydrolysis conditions. Food Additives and Contaminants, 12(4), 527-533. doi https://doi.org/10.1080/02652039509374341

Chongtham, N., Bisht, M. S., Premlata, T., Bajwa, H. K., Sharma, V., \& Santosh, O. (2021). Quality improvement of bamboo shoots by removal of antinutrients using different processing techniques: A review. Journal of Food Science and Technology. doi: https://doi.org/10.1007/s13197-021-04987-9

Ionescu, I. A., López-Ortega, G., Burow, M., Bayo-Canha, A., Junge, A., Gericke, O., ... Sánchez-Pérez, R. (2017). Transcriptome and Metabolite Changes during Hydrogen Cyanamide-Induced Floral Bud Break in Sweet Cherry. Frontiers in Plant Science, 8. doi: https://doi.org/10.3389/fpls.2017.01233

Jiu, S., Xu, Y., Wang, J., Wang, L., Liu, X., Sun, W., ... Zhang, C. (2020). The Cytochrome P450 Monooxygenase Inventory of Grapevine (Vitis vinifera L.): Genome-Wide Identification, Evolutionary Characterization and Expression Analysis. Frontiers in Genetics, 11. doi: https://doi.org/10.3389/fgene.2020.00044 Klein, J., Zikeli, S., Claupein, W., \& Gruber, S. (2017). Linseed (Linum usitatissimum) as an oil crop in organic farming: abiotic impacts on seed ingredients and yield. Organic Agriculture, 7(1), 1-19. doi: https://doi.org/10.1007/s13165-016-0146-6

Krech, M. J., \& Fieldes, M. A. (2003). Analysis of the developmental regulation of the cyanogenic compounds in seedlings of two lines of Linum usitatissimum $\mathrm{L}$. Canadian Journal of Botany, 81(10), 1029-1038. doi: https://doi.org/10.1139/b03097

Kudłak, B., Wieczerzak, M., \& Namieśnik, J. (2017). Cyanogenic Compounds and Estrogen Disruptors. Toxins and Other Harmful Compounds in Foods, 243-251. https://mostwiedzy.pl/pl/publication/cyanogenic-compounds-and-estrogendisruptors, 140373-1

Kyoto Encyclopedia of Genes and Genomes (KEGG). (2021). KEGG PATHWAY: Cyanoamino acid metabolism - Reference pathway. https://www.kegg.jp/kegg-bin/show_pathway?map00460+C08325

Lechtenberg, M. (2011). Cyanogenesis in Higher Plants and Animals. eLS. doi: https://doi.org/10.1002/9780470015902.a0001921.pub2

Lei, V., Amoa-Awua, W.K.A., Brimer, L. (1999). Degradation of cyanogenic glycosides by Lactobacillus plantarum strains from spontaneous cassava fermentation and other microorganisms. International Journal of Food Microbiology. 53(2-3), 169-184. doi: https://doi.org/10.1016/s01681605(99)00156-7

Li, X., Li, J., Dong, S., Li, Y., Wei, L., Zhao, C., ... Wang, Y. (2019). Effects of germination on tocopherol, secoisolarlciresinol diglucoside, cyanogenic glycosides and antioxidant activities in flaxseed (Linum usitatissimumL.).
International Journal of Food Science \& Technology, 54(7), 2346-2354. doi: https://doi.org/10.1111/ijfs.14098

Lindinger, M. I. (2019). Ground Flaxseed - How Safe is it for Companion Animals and for Us? Veterinary Science Research, 1(1). doi https://doi.org/10.30564/vsr.v1i1.1158

Martinez Ruiz, M. G., Richard-Greenblatt, M., Juarez, Z. N. et al. (2012) Antimicrobial, Anti-Inflammatory, Antiparasitic, and Cytotoxic Activities of Laennecia confusa. Scientific World Journal, Article Number: 263572. doi: https://doi.org/10.1100/2012/263572

Menon, R., Munjal, N., Sturino, J.M. (2015). Characterization of amygdalindegrading Lactobacillus species. Journal of Applied Microbiology, 118(2), 443 453. doi: https://doi.org/10.1111/jam.12704

MetaCyc. (2021). MetaCyc lotaustralin biosynthesis https://biocyc.org/META/NEW-IMAGE?type=PATHWAY\&object=PWY-5990 Mhawesh, A., Al-Ugaili, D., \& Olaiwy, Y. (2018) Investigate the antibacterial activity of amygdalin against some types of antibiotic resistant pathogenic bacteria Basrah Journal of Veterinary Research, 17(3), 575-592. https://basjvet.org/uplodes/pdf/1589052249.pdf

Mobot. (2021). Evolution of land plants (under construction) http://www.mobot.org/moBot/research/apweb/orders/Sporing.html

Mosayyebi, B., Imani, M., Mohammadi, L., Akbarzadeh, A., Zarghami, N., Edalati, M., ... Rahmati, M. (2020). An update on the toxicity of cyanogenic glycosides bioactive compounds: Possible clinical application in targeted cancer therapy. Materials Chemistry and Physics, 246, 122841. doi https://doi.org/10.1016/j.matchemphys.2020.122841

Muir, A. D., \& Westcott, N. D. (2003). Flax: the genus Linum. CRC press https://books.google.sk/books?id=OsMR6zV26-sC

Nadayag, J., Dapar, M. L. G., Aranas, A.T. et al. (2019). Qualitative assessment of the antimicrobial, antioxidant, and phytochemical properties of the ethanolic extracts of the inner bark of Atuna racemosa. Pharmacophore, 10(1), 59-52. doi: Niedźwiedź-Siegień, I. (1998). Cyanogenic Glucosides In Linum Usitatissimum. Phytochemistry, 49(1), 59-63. doi: https://doi.org/10.1016/s0031-9422(97)009539

Niedźwiedź-Siegień, I., \& Gierasimiuk, A. (2001). Environmental factors affecting the cyanogenic potential of flax seedlings. Acta Physiologiae Plantarum, 23(4), 383-390. doi: https://doi.org/10.1007/s11738-001-0047-4

Nielsen, L. J., Stuart, P., Pičmanová, M., Rasmussen, S., Olsen, C. E., Harholt, J.,

.. Bjarnholt, N. (2016). Dhurrin metabolism in the developing grain of Sorghum bicolor (L.) Moench investigated by metabolite profiling and novel clustering analyses of time-resolved transcriptomic data. BMC Genomics, 17(1). doi: https://doi.org/10.1186/s12864-016-3360-4

Nwankwo, I. U., Onwuakor, C. E., \& Nwosu, V. C. (2014). Phytochemical analysis and antibacterial activities of Citrullus lanatus seed against some pathogenic microorganisms. Global Journal of Medical Research, 14(4), 0975-5888. https://bit.ly/3nS6ZM3

Nwaogu, L. A., Alisi, C. S., Igwe, C. U. et al. (2008). A comparative study of the antimicrobial properties of the ethanolic extracts of Landolphia owariensis leaf and root. African Journal of Biotechnology, 7( 4), 368-372.

Nyirenda, K. (2020). Toxicity Potential of Cyanogenic Glycosides in Edible Plants. Medical Toxicology. doi: https://doi.org/10.5772/intechopen.91408

Obi, R. K., Nwanebu, F. C., Ndubuisi, U.U. et al. (2009) Antibacterial qualities and phytochemical screening of the oils of Curcubita pepo and Brassica nigra. Journal of Medicinal Plants Research, 432-429), 5(3 .

O'Donnell, N.H., Moller, B.L., Neale, A.D. et al. (2013). Effects of PEG-induced osmotic stress on growth and dhurrin levels of forage sorghum. Plant Physiology And Biochemistry. 73,92-83 . doi: https://doi.org/10.1016/j.plaphy.2013.09.001 Oomah, B. D., Mazza, G., \& Kenaschuk, E. O. (1992). Cyanogenic compounds in flaxseed. Journal of Agricultural and Food Chemistry, 40(8), 1346-1348. doi https://doi.org/10.1021/jf00020a010

Oros, G., \& Kállai, Z. (2019). Phytoanticipins: The Constitutive Defense Compounds as Potential Botanical Fungicides. Bioactive Molecules in Plant Defense, 179-229. doi: https://doi.org/10.1007/978-3-030-27165-7_11

Panter, K. E. (2018). Cyanogenic Glycoside-Containing Plants. Veterinary Toxicology, 935-940. doi: https://doi.org/10.1016/b978-0-12-811410-0.00064-7 Pičmanová, M., Neilson, E. H., Motawia, M. S., Olsen, C. E., Agerbirk, N., Gray, C. J., ... Bjarnholt, N. (2015). A recycling pathway for cyanogenic glycosides evidenced by the comparative metabolic profiling in three cyanogenic plant species. Biochemical Journal, 469(3), 375-389. doi: https://doi.org/10.1042/bj20150390

Russo, R., \& Reggiani, R. (2014). Variation in the Content of Cyanogenic Glycosides in Flaxseed Meal from Twenty-One Varieties. Food and Nutrition Sciences, 05(15), 1456-1462. doi: https://doi.org/10.4236/fns.2014.515159 
Senica, M., Stampar, F., Veberic, R., \& Mikulic-Petkovsek, M. (2019) Cyanogenic glycosides and phenolics in apple seeds and their changes during long term storage. Scientia Horticulturae, 255, 30-36. doi: https://doi.org/10.1016/j.scienta.2019.05.022

Schmidt, F. B., Cho, S.K., Olsen, C.E. et al. (2018). Diurnal regulation of cyanogenic glucoside biosynthesis and endogenous turnover in cassava. Plant Direct, 2(2), Article Number: 38. https://doi.org/https://doi.org/10.1002/pld3.38 Schrenk, D., Bignami, M., Bodin, L., Chipman, J. K., del Mazo, J., Grasl-Kraupp, B., $\quad \ldots \quad \&$ Schwerdtle, T. (2019). SCIENTIFIC OPINION. doi: https://doi.org/10.2903/j.efsa.2019.5662

Siegień, I. (2007). Cyjanogeneza u roślin i jej efektywność w ochronie roślin przed atakiem roślinożerców i patogenów. Kosmos, 56(1-2), 155-166 http://kosmos.icm.edu.pl/PDF/2007/155.pdf

Siegień, I., Adamczuk, A., \& Wróblewska, K. (2012). Light affects in vitro organogenesis of Linum usitatissimum L. and its cyanogenic potential. Acta Physiologiae Plantarum, 35(3), 781-789. doi: https://doi.org/10.1007/s11738-0121118-4

Sørensen, M., Neilson, E. H. J., \& Møller, B. L. (2018). Oximes: Unrecognized Chameleons in General and Specialized Plant Metabolism. Molecular Plant, 11(1), 95-117. doi: https://doi.org/10.1016/j.molp.2017.12.014

Süli, J. U. D. I. T., Sobeková, A., \& Bujdošová, Z. (2017). Antinutričné látky v strukovinách. Chemické listy, 111(12), 789-797. http://chemickelisty.cz/docs/full/2017_12_789-797.pdf

Sun, Z., Zhang, K., Chen, C., Wu, Y., Tang, Y., Georgiev, M. I., ... Zhou, M. (2017). Biosynthesis and regulation of cyanogenic glycoside production in forage plants. Applied Microbiology and Biotechnology, 102(1), 9-16. doi: https://doi.org/10.1007/s00253-017-8559-Z

Thodberg, S., Sørensen, M., Bellucci, M., Crocoll, C., Bendtsen, A. K., Nelson, D. R., ... Neilson, E. H. J. (2020). A flavin-dependent monooxygenase catalyzes the initial step in cyanogenic glycoside synthesis in ferns. Communications Biology, 3(1). doi: https://doi.org/10.1038/s42003-020-01224-5

Van Ohlen, M., Herfurth, A.-M., \& Wittstock, U. (2017). Herbivore Adaptations to Plant Cyanide Defenses. Herbivores. doi: https://doi.org/10.5772/66277

Vetter, J. (2017). Plant Cyanogenic Glycosides. Toxinology, 287-317. doi https://doi.org/10.1007/978-94-007-6464-4_19

Wang, H., Wang, J., Guo, X., Brennan, C. S., Li, T., Fu, X., ... Liu, R. H. (2016) Effect of germination on lignan biosynthesis, and antioxidant and antiproliferative activities in flaxseed (Linum usitatissimum L.). Food Chemistry, 205, 170-177. doi: https://doi.org/10.1016/j.foodchem.2016.03.001

Waszkowiak, K., Gliszczyńska-Świgło, A., Barthet, V., \& Skręty, J. (2015). Effect of Extraction Method on the Phenolic and Cyanogenic Glucoside Profile of Flaxseed Extracts and their Antioxidant Capacity. Journal of the American Oil Chemists' Society, 92(11-12), 1609-1619. doi: https://doi.org/10.1007/s11746015-2729-X

Yeats, T. H. (2018). Setting and Diffusing the Cyanide Bomb in Plant Defense. Plant Physiology, 178(3), 956-957. doi: https://doi.org/10.1104/pp.18.01214

Yulvianti, M., \& Zidorn, C. (2021). Chemical Diversity of Plant Cyanogenic Glycosides: An Overview of Reported Natural Products. Molecules, 26(3), 719. doi: https://doi.org/10.3390/molecules26030719

Zhong, Y., Xu, T., Chen, Q., Li, K., Zhang, Z., Song, H., ... Lu, B. (2020) Development and validation of eight cyanogenic glucosides via ultra-highperformance liquid chromatography-tandem mass spectrometry in agri-food. Food Chemistry, 331, 127305. doi: https://doi.org/10.1016/j.foodchem.2020.127305

Zuk, M., Pelc, K., Szperlik, J., Sawula, A., \& Szopa, J. (2020). Metabolism of the Cyanogenic Glucosides in Developing Flax: Metabolic Analysis, and Expression Pattern of Genes. Metabolites, 10(7), 288. doi:

https://doi.org/10.3390/metabo10070288 